\title{
MICROWAVE SUPPORTED TREATMENT OF SEWAGE SLUDGE
}

\author{
František Janíček ${ }^{*}$ - Milan Perný ${ }^{*}$ \\ Vladimír Šály ${ }^{*}$ — Markus Giemza ${ }^{* *}$ — Peter Hofmann ${ }^{* * *}$
}

\begin{abstract}
This work is focused on microwave treatment of sewage sludge. The aim of our experiments was to investigate the impact of microwave radiation upon different sewage sludge parameters such as concentration of nitrates and nitrites, phosphates, COD (Chemical Oxygen Demand), SVI (Sludge Volume Index) and the microscopic structure of sludge. The experiments with microwave irradiation of sewage sludge indicate that moderate microwave power causes visible effects on the chemical, physical and biological properties of the sludge. The calculation of profitability and energy efficiency is also presented.
\end{abstract}

K e y w o r d s: gasification, microwave radiation, microwave reactors, waste

\section{INTRODUCTION}

Due to the legislation of the EU and its incorporation into the legislation of individual EU countries a big emphasis is put on the deployment of renewable energy [1]. In Slovakia, eg, the greatest potential has the energy from biomass, followed by solar, geothermal, hydro and wind energy. In the future, more than $80 \%$ of this potential is technically exploitable for energy production $[2,3]$. Except of energy production RES have got important impact on rural employment which includes new activities such as landscape protection and development with regard to ecology [4].

Waste generation has a serious impact on the environment, causing pollution and greenhouse gases emission, as well as significant losses of materials a particular problem for the EU which is strongly dependent on imported raw materials [5]. According to the estimation of the European Commission for the period between 2006 and 2010, about 10 million tons of dry material of sewage sludge was generated every year [6]. The restrictive EU legal regulations have led to solutions enabling rubber wastes to be converted into energy or new polymer materials [7] and support the total energy balance.

There are three main ways how to recover energy from waste:

- Anaerobic digestion - decomposition of organic matter by microorganisms in the absence of oxygen,

- Incineration - direct combustion,

- Thermal decomposition - pyrolysis/gasification Advanced Thermal Treatment (ATT).

Pyrolysis is the thermo-chemical decomposition of carbon-based (organic) materials at high temperature. Pyrolysis is the first step in gasification and combustion and occurs in the absence or nearly absence of oxygen [8].
Gasification is also a thermo-chemical process similar to pyrolysis, however, it involves partial oxidation, therefore it can be considered as a process between pyrolysis and combustion [9].

Typically, pyrolysis and gasification run better with a consistent feedstock. Unsorted municipal waste as not consistent and not homogeneous material is usually not suitable for ATT, therefore some mechanical preparation and separation of glass, metals and inert materials (such as rubble) is required prior to thermal waste processing. This is the reason for a limited track record of the use of pyrolysis and gasification in Europe on a commercial scale in the processing of municipal waste. Another situation can be observed for example in Japan. For a number of years, almost all new plants for thermal waste processing are based on gasification or pyrolysis and they have worked reliably. Waste treatment technology should work efficiently and almost dioxin-free in all output flows, including fly ash, slag and gas cleaning salts. The residues are often converted to glass granulates, from which secondary raw material can be recovered, for example for road construction. This also ensures that landfilling can be mostly avoided [10]. Figure 1 shows a typical Waste to Energy (WtE) solution by gasification of refuse-derived fuel (RDF). RDF is usually produced from residue waste which cannot be reused or recycled, for example as a byproduct of mechanical biological treatment (MBT) of municipal waste.

In the process shown in Fig. 1 syngas is produced through gasification of RDF, which is purified and then burned in a gas engine or gas turbine for generation of electricity. Syngas, or synthesis gas, is a fuel gas mixture consisting primarily of hydrogen, carbon monoxide, and very often some carbon dioxide. The name comes from its use as intermediates in creating synthetic natural gas [11].

Institute of Power and Applied Electrical Engineering, Faculty of Electrical Engineering and Information Technology, Slovak University of Technology Bratislava, Slovakia, frantisek.janicek@stuba.sk; ${ }^{* *}$ Giemza Industrieanlagen, Asslar, Germany, mgiemza@aol.com; *** Hofmann Energy-Systems, Dillenburg, Germany, hofmann-experts@online.de 


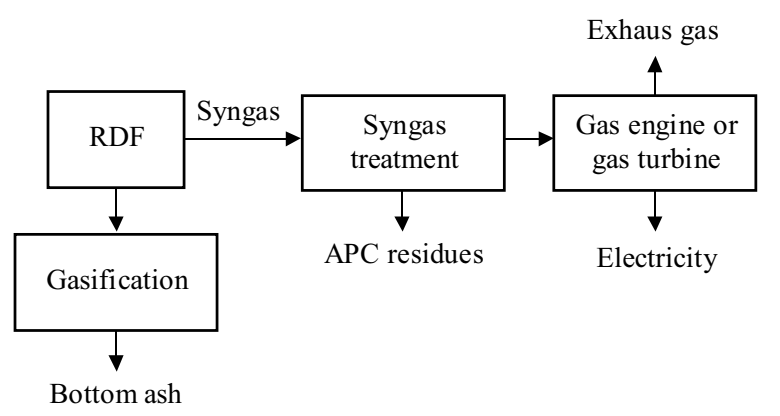

Fig. 1. Energy recovery from RDF by gasification

This system is more efficient and provides better energy conversion compared with incineration [12].

Due to specific effects of microwave irradiation and different interaction mechanisms with materials [13] the technology which uses microwaves for heating may be advantageous in energy recovery from waste by gasification. The positive experience in the chemical industry (microwave chemistry) and food industry may indicate that microwave application can be an interesting approach even in ATT.

\section{EXPERIMENT}

The series of experiments with gasification of different waste samples were carried out at the company Aton S. A. in Stradomia Wierzchnia (Poland). The microwave reactors used in these experiments were designed and built by Aton S. A. These series of tests were conducted on behalf of the company ASSA Ewenex Energy. Gasification of the waste was carried out in the laboratory microwave reactor HR-Lab whereas the microwave-assisted oxidation of syngas took place in reactor MOS. A small part of the tests with biomass was performed in the larger microwave reactor HR 200, which may be considered as upscaling and yields results comparable with the pilot tests. The microwave reactors HR-Lab and HR 200 differ only in size, whereas the operating and construction principles are the same. Figure 2 shows the two reactors HR-Lab and MOS used in the experiments.

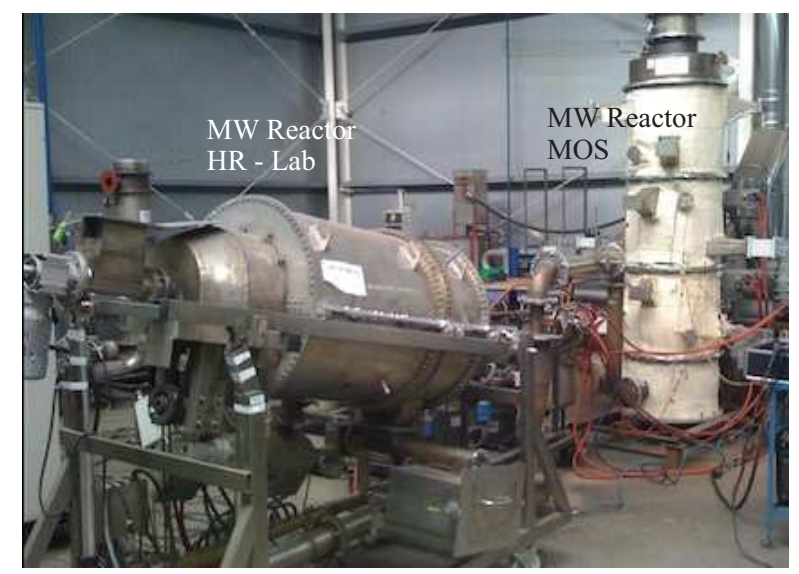

Fig. 2. Microwave reactors HR-Lab and MOS
Microwave reactor HR is a continuous laboratory rotary kiln consisting of a ceramic drum located within a metal casing with microwave transmitters fixed to its walls. By rotation of the ceramic drum the material is distributed and transported physically over the entire crosssection. The microwave reactor MOS is used in our experiments for oxidation of the outlet gas of the gasifier. The reactor includes a reactor chamber in the form of a cylindrical container with a porous material bed, an inlet and outlet for exhaust gases and at least one microwave emitter connected to the microwave generator. The microscope HUND type Will H 500 that allows magnifications up to 1000 was used for microscopic analysis.

\section{RESULTS AND DISCUSSION}

Two settings were investigated: variable irradiation time at a constant power and variable power at a constant time in the first series of experiment.

\section{Temperature}

The temperature during the process, as one of the most important parameters, was measured for each sample. The dependence of temperature in the chamber at a constant irradiation time and variable power is shown in Fig. 3.

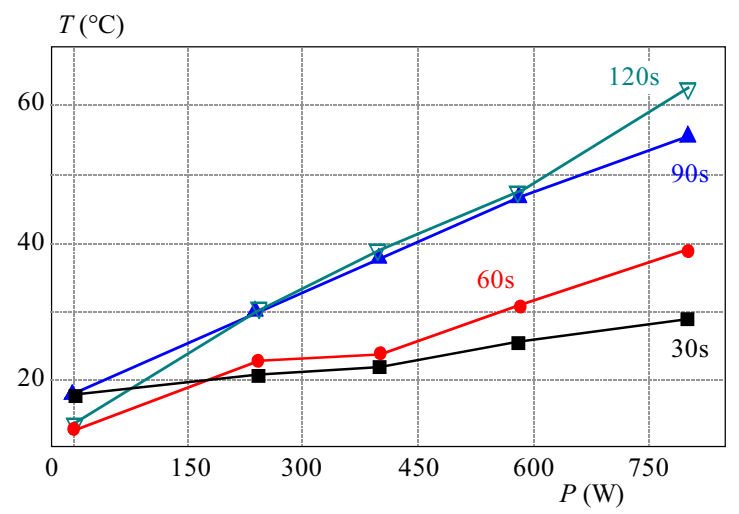

Fig. 3. Temperature achieved at constant duration and variable power of irradiation

\section{Ammonium nitrogen}

The concentration of ammonium nitrogen in the sludge from aeration tanks is usually low. Nevertheless, it is interesting to see how microwave irradiation can affect the ammonium concentration (Fig. 4) because this parameter can be important for biogas generation.

The strongest influence on the concentration of $\mathrm{NH}_{4}-$ $\mathrm{N}$ was observed at irradiation time of $120 \mathrm{~s}$ and at the output power of $400 \mathrm{~W}$. At a shorter exposure time, at $60 \mathrm{~s}$, the highest value of $\mathrm{NH}_{4}-\mathrm{N}$ concentration was measured at irradiation with a power of $800 \mathrm{~W}$. At $90 \mathrm{~s}$ of irradiation the strongest effect had the power of $580 \mathrm{~W}$. 


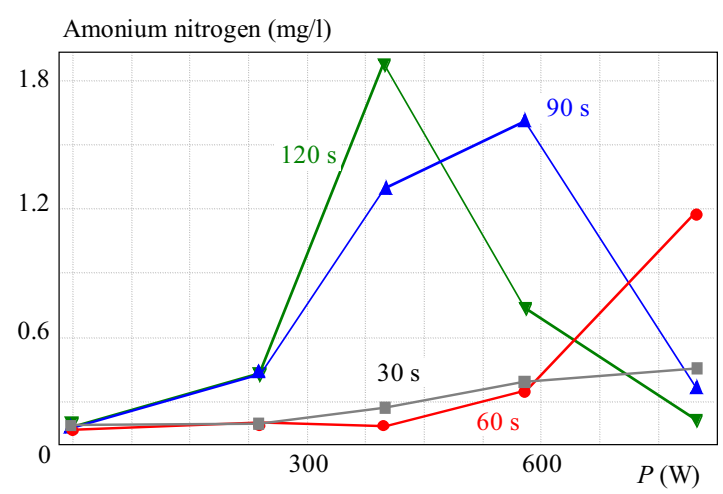

Fig. 4. Ammonium concentration at constant duration and variable power

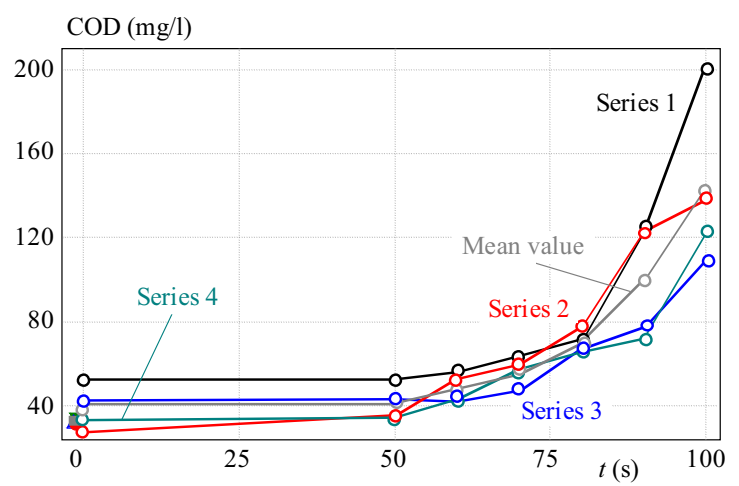

Fig. 5. COD concentration at the power of $580 \mathrm{~W}$

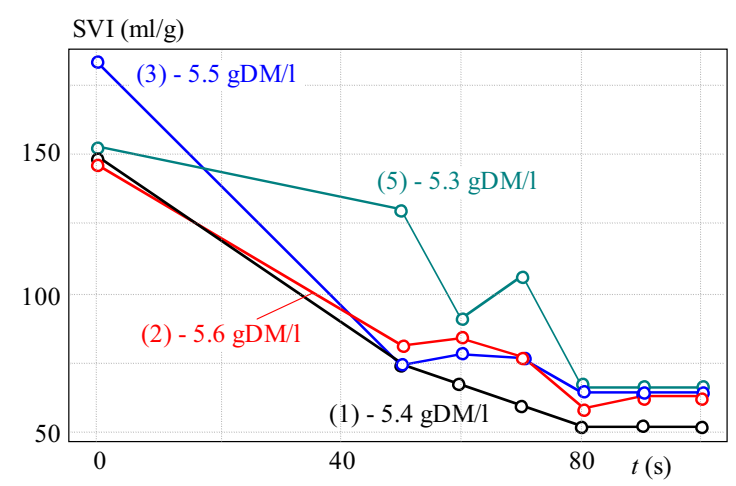

Fig. 6. Sludge Volume Index at a power of $580 \mathrm{~W}$

The irradiation time of $30 \mathrm{~s}$ was too short to cause any significant changes, regardless of the power range.

Analyses of the dependences of nitrite and nitrate, phosphate concentrations and of COD for a constant power and different irradiation times were done (but the plots are not presented here). At the irradiation time 120 $\mathrm{s}$ and $90 \mathrm{~s}$ and power $580 \mathrm{~W}$ the concentration of nitrite attained the highest value. The irradiation time of $30 \mathrm{~s}$ seems to have only a weak effect on the nitrate concentration at all investigated microwave power levels.

Irradiation for $120 \mathrm{~s}$ and $90 \mathrm{~s}$ with a power of 400 $\mathrm{W}$ caused a drop in nitrate concentration. At a power of $580 \mathrm{~W}$ and irradiation time $120 \mathrm{~s}$ the concentration was already higher. Irradiation with $800 \mathrm{~W}$ did not lead to a significant difference. The power of $580 \mathrm{~W}$ seems to have already a significant effect on the concentration of nitrate in the investigated process.

The phosphate concentration at powers of 580 and $800 \mathrm{~W}$ increased noticeably already after $30 \mathrm{~s}$ of heating. The irradiation for $120 \mathrm{~s}$ was needed to obtain similar results when $400 \mathrm{~W}$ was applied. The highest energy input caused the highest increase of COD. Irradiation with powers $800 \mathrm{~W}$ for $120 \mathrm{~s}$ boosted the COD from $68 \mathrm{mg} / \mathrm{l}$ to $611 \mathrm{mg} / \mathrm{l}$, what makes almost $900 \%$ increases. Significant changes were noticed already after $90 \mathrm{~s}$ irradiation with the power of $580 \mathrm{~W}$, from $48.5 \mathrm{mg} / \mathrm{l}$ to $149.5 \mathrm{mg} / \mathrm{l}$ (increase by about $300 \%$ ).

The second series of tests were continued with at constant power and variable irradiation time. As the best compromise between economy and efficiency, the power of $580 \mathrm{~W}$ was chosen with intention to assess the changes at the lowest energy input that still brings visible results. Therefore this power range was used for subsequent investigations and the results are explained in detail below. The maximum temperature after $100 \mathrm{~s}$ of irradiation with $580 \mathrm{~W}$ was $45.7{ }^{\circ} \mathrm{C}$. At this temperature only the first phase of the process can normally occur in the thermal disintegration, which includes decomposition of biopolymers and a limited damage of cell walls of microorganisms. It was further found that at the irradiation time of $80 \mathrm{~s}$ the $\mathrm{NO}_{3}-\mathrm{N}$ concentration level was at the lowest value and from $90 \mathrm{~s}$ it increased strongly. There were only small changes in phosphate concentration observed during the first $60 \mathrm{~s}$. The first relevant change was observed after $60 \mathrm{~s}$ and the next measurement at $80 \mathrm{~s}$ of irradiation detected a marked increase of the phosphate concentration. The concentration of phosphate increased by a factor of 8 after $120 \mathrm{~s}$ of irradiation. Biological availability of phosphorus is crucial for the growth of microorganisms and a lack of phosphate leads to stopping their metabolism because phosphate is required for the formation of the energy transporters ATP (adenosine triphosphate) and NADP (nicotinamide adenine dinucleotide phosphate) [14].

COD is one of the most important parameters in wastewater treatment and is usually used to determine the amount of organic compounds in water in an indirect way. After $80 \mathrm{~s}$ of exposure the gradient of COD becomes steeper - more organic substances are released into water.

The Sludge Volume Index (SVI) is a most widely applied test for sludge settling velocity. The results of this test are shown in Fig. 6. In the first phase of irradiation with $580 \mathrm{~W}$ (up to $50 \mathrm{~s}$ ) SVI decreased strongly. In the last phase, after $80 \mathrm{~s}$, the SVI reached its lowest value.

However, after microwave irradiation with a higher energy input (longer exposure and/or higher power) it was observed that the sludge tended to float up. Within the investigated power range and irradiation time (maximum $800 \mathrm{~W}$ and $120 \mathrm{~s}$ ) it was found that the higher the energy input the more pronounced the floating up. This undesired effect of floating up after irradiation with the power of $800 \mathrm{~W}$ is shown in Fig. 7 . 


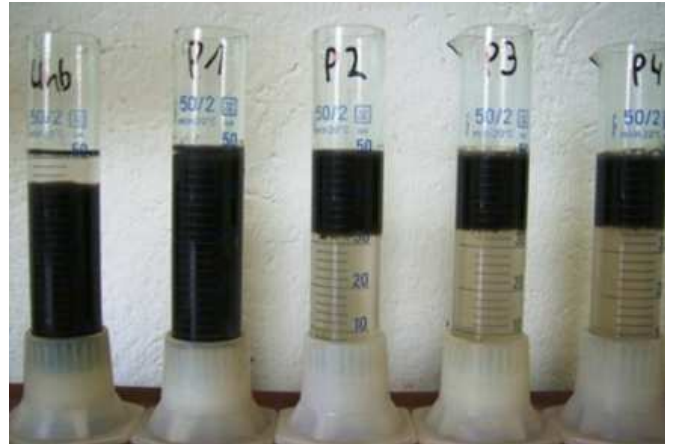

Fig. 7. Floating up of sludge irradiated with $800 \mathrm{~W}$

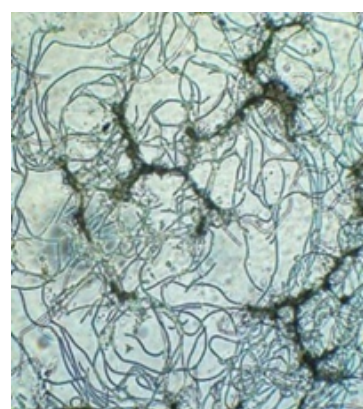

(a)

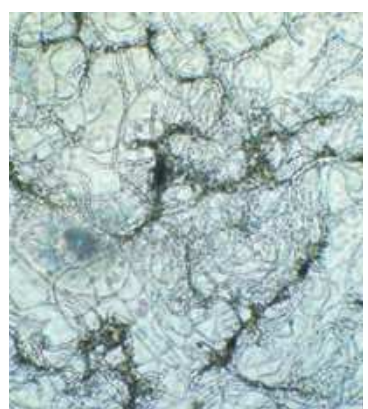

(b)
Fig. 9. Sludge: (a) - after $800 \mathrm{~W}$ during $60 \mathrm{~s}$, and (b ) $-800 \mathrm{~W}$ during $90 \mathrm{~s}$

\section{Microscopic analysis}

The micrograph made during this investigation confirmed the changes in the sludge structure and appearance that were caused by microwave irradiation. All pictures are made with magnification 400. The first picture (Fig. 8 left) shows the fresh sludge before microwave irradiation. In the picture a sludge flock with irregular structure and some filamentous bacteria is visible. Figure 8 right shows the sludge flock after $30 \mathrm{~s}$ of microwave irradiation with power of $800 \mathrm{~W}$.

The flock structure was becoming loose-packed and more filamentous bacteria are visible. The next picture (Fig. 9 left) shows the sludge after $60 \mathrm{~s}$ of irradiation with a power of $800 \mathrm{~W}$. The flock structure was becoming less visible and the filamentous bacteria occupied the space. The next pictures show the sludge after 90 and $120 \mathrm{~s}$ of exposure to microwaves (Figs. 9 and 10).

Microwave irradiation with a power of $580 \mathrm{~W}$ did not destroy the cell structures of all microorganisms. After 80 $\mathrm{s}$ of irradiation the rotifers (wheel animals) are still vivid and active (Fig. 10 right).

Energy efficiency is a decisive factor in determining the economic feasibility of every industrial process. The amount of energy consumed for the generation of microwaves has to be reflected in an adequate increase in the biogas amount. For this reason, we have calculated which specific energy was consumed in the sludge mi-

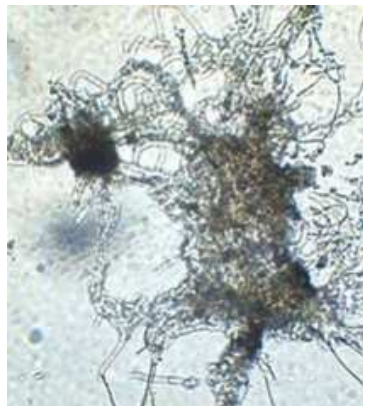

(a)

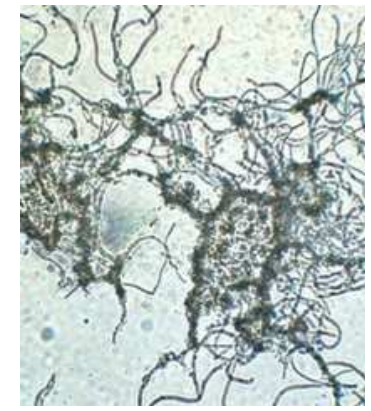

(b)
Fig. 8. Sludge: (a) — before, and (b) — after $30 \mathrm{~s}$ irradiation

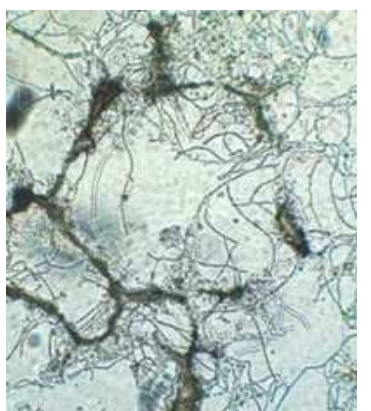

(a)

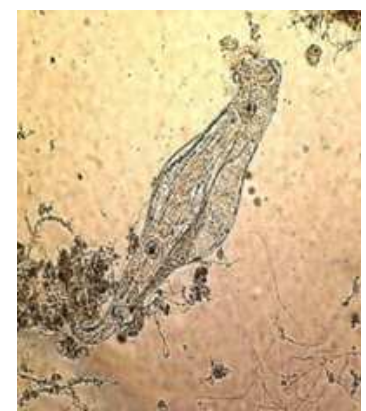

(b)
Fig. 10. 10 Sludge: (a) — after $800 \mathrm{~W}$ during $120 \mathrm{~s}$, and $580 \mathrm{~W}$ during $80 \mathrm{~s}$

crowave pre-treatment and compared it with the possible energy yield increases resulting from the elevated biogas production.

Equation describing the amount of energy that has been consumed per unit mass (in $\mathrm{kJ} / \mathrm{kg}$ ) of the dry substance (specific energy input) of irradiated sludge can be estimated as

$$
E_{i}=\frac{P_{\mathrm{MW}} T_{\mathrm{i}}}{M_{\mathrm{TS}}} \quad \text { where } \quad M_{\mathrm{TS}}=V_{\mathrm{s}} T S
$$

where $P_{\mathrm{MV}}$ - is the supplied microwave power $(\mathrm{kW})$ and $T_{\mathrm{i}}$ - is the irradiation time, $M_{\mathrm{TS}}$ - is the mass of the dry substance, expressed as volume of the sample $\left(V_{\mathrm{s}}\right)$ multiplied by the mean amount of the dry substance $T S$. The latter is defined as mass per volume (most commonly $\mathrm{mg} / \mathrm{l}$ ) after the sample has been dried in an oven for 24 hours at $103{ }^{\circ} \mathrm{C}$.

The results of the specific energy calculation consumed for microwave irradiation are included in Tab. 1.

The experiments have shown that moderate microwave irradiation can lead to disintegration of the sludge, thus increasing the dewaterability, improving the flock structure and thereby releasing also substances that promote biogas formation. Small power inputs up to $400 \mathrm{~W}$ and short irradiation times did not bring about significant changes in the sludge properties. Generally, it can be noted that the solubility of the sludge increased with increasing specific energy input. 
Table 1. Specific energy $E_{i}$ consumed by MW pre-treatment in $\mathrm{MJ} / \mathrm{kg}$

\begin{tabular}{cccccc}
\hline Irradiation & \multicolumn{6}{c}{ Specific energy at given microwave pover $(\mathrm{MJ} / \mathrm{kg})$} \\
time $T_{i}(\mathrm{~s})$ & $80 \mathrm{~W}$ & $240 \mathrm{~W}$ & $400 \mathrm{~W}$ & $580 \mathrm{~W}$ & $800 \mathrm{~W}$ \\
\hline 50 & 2.47 & 7.41 & 12.35 & 17.90 & 24.69 \\
60 & 2.96 & 8.89 & 14.81 & 21.48 & 29.63 \\
70 & 3.46 & 10.37 & 17.28 & 25.06 & 34.57 \\
80 & 3.95 & 11.85 & 19.75 & $\underline{28.64}$ & 39.51 \\
90 & 4.44 & 13.33 & 22.22 & 32.22 & 44.44 \\
100 & 4.94 & 14.81 & 24.69 & 35.80 & 49.38 \\
120 & 5.93 & 17.78 & 29.63 & 42.96 & 59.26 \\
\hline
\end{tabular}

The experiments have also shown that the effect was not significant with the supplied microwave power of less than $580 \mathrm{~W}$ and irradiation time of $80 \mathrm{~s}$, which corresponds to the input of specific energy $E_{\mathrm{i}}$ of $28.64 \mathrm{MJ} / \mathrm{kg}$ of TS.

For a positive energy balance the consumed energy has to be lower than the energy gain from the increased biogas yield $E_{0}$. The energy consumption ratio (ECR) can be defined as

$$
E C R=\frac{E_{\mathrm{i}}}{E_{0}}, \quad \text { with: } \quad E_{0}=\Delta P_{\text {biogas }} \zeta_{\text {biogas }}
$$

where $\Delta P_{\text {biogas }}$ is the increase of biogas yield $\left(\mathrm{dm}^{3} / \mathrm{kg}\right)$ and $\zeta_{\text {biogas }}$ is the lower heating value of biogas $\left(\mathrm{MJ} / \mathrm{m}^{3}\right)$.

For the calculation of biogas plants it can be assumed that the biogas lower heating value $\zeta_{\text {biogas }}$ lies between 18 and $27 \mathrm{MJ} / \mathrm{m}^{3}$ ( 5 to $7.5 \mathrm{kWh} / \mathrm{m}^{3}$ ), which correspond to the methane content between 50 and $75 \%$ [15].

The biogas yield from excess sewage sludge without pre-treatment can be between 0.25 and $0.30 \mathrm{~m}^{3} \mathrm{~N} / \mathrm{kg}$. Excess sludge is in comparison to the primary sludge relatively poorly biodegradable [16]. Dry matter (TS) consists of organic matter and of non-biodegradable mineral substance (often about 25\%).

Abwassertechnische Vereinigung (ATV) [17] compared different thermal disintegration processes and noted that at the temperatures lower than $100{ }^{\circ} \mathrm{C}$ under atmospheric pressure the increase in the amount of biogas generation can be between 15 and $50 \%$.

The range of the expected specific energy output is assumed by the respective lowest $E_{01}=0.675 \mathrm{MJ} / \mathrm{kg}$ and the highest $E_{0 \mathrm{~h}}=4.05 \mathrm{MJ} / \mathrm{kg}$. The energy consumption ratio (for the power $580 \mathrm{~W}$ and duration of $80 \mathrm{~s}$ ) is between $E C R_{\mathrm{l}}=42.43$ and $E C R_{\mathrm{h}}=7.07$ respectively.

These results mean that the energy balance is highly negative and more energy is consumed than could be gained by expected increase of biogas generation. These values correspond to a totally dry substance but not to an organic dry substance. Actually, the energy consumption ratio was by about $25 \%$ higher because biogas is only generated by conversion of organic matter.

\section{CONCLUSIONS}

The experiments with microwave irradiation of waste sewage sludge indicate that moderate microwave power causes visible effects in the chemical, physical and biological sludge properties. Accelerated denitrification was visible already in the initial phase of microwave irradiation. The concentration of phosphate increased by a factor 8 after irradiation for $120 \mathrm{~s}$. The results of the experiments indicate that the first phase of sludge disintegration occurs also at a lower microwave power of $580 \mathrm{~W}$ and irradiation time of $70 \mathrm{~s}$. In this phase hydrolysis of large biopolymers and their decomposition into smaller particles was observed as well as partial destroying of some microorganisms resulting in increased solubility of the sludge but not all cell walls were cracked.

The calculation of energy balance did not show economical profit but from the technical point of view the application of MW heating is improving the process.

\section{Acknowledgement}

This work is the result of the project Competence center for new materials, advanced technologies and energy ITMS 26240220073, supported by the Research and Development Operational Program funded by the Euroropean Regional Development Fund.

\section{REFERENCES}

[1] MARKO, Š.-DARULA, I. : Large Scale Integration of Renewable Electricity Production into the Grids, Journal of Electrical Engineering 58 No. 1 (2007), 5860.

[2] JANÍČEK, F.-DARULA, I.-GADUŠ, J.-REGULA, E.SMITKOVÁ, M.-POLONEC,.—L'UDVÍK, J.—KUBICA, J.: Renewable Energy Sources 1., Renesans s.r.o., Pezinok, SR, 2009

[3] JANÍČEK, F.-GADUŠ, J.-ŠÁLY, V.—DARULA, I.-REGULA, E.-SMITKOVÁ, M.-KUBICA, J.-PÍPA, M-—BINDZÁR, M.: Renewable Energy Sources 2. Prospective conversions and technologies, Renesans s.r.o., Pezinok, SR, 2012.

[4] NÉMEThOVÁ, J.-DUBCOVÁ, A.—KRAMÁREKOVÁ, H. : The Impacts of the European Union's Common Agricultural Policy on Agriculture in Slovakia, MORAVIAN GEOGRAPHICAL REPORTS 22 No. 4 (2014), 51-64.

[5] EUROPEAN-COMMISSION : Being wise with waste: the EU's approach to waste management, Publications Office of the European Union, Luxemburg, LU, 2010.

[6] GENDEBEIN, A.: Environmental, economic and social impacts of the use of sewage sludge on land, Summary Report 1, Assessment of Existing Knowledge, Milieu Ltd, WRc and RPA for the European Commission, Brussel, BG, 2008. 
[7] SIENKIEWICZ, M.-KUCINSKA-LIPKA, J.-JANIK, H.BALAS, A.: Progress in used tyres management in the European Union: A review, Waste Management 32 No. 10 (2012), 1742-1751.

[8] ENCYCLOPAEDIA-BRITANNICA : accessed Sept. 2014, available at: http://www.britannica.com/EBchecked/topic /484978/pyrolysis.

[9] DEFRA : Department for Environment Food \& Rural Affairs: Advanced Thermal Treatment of Municipal Solid Waste, 2013, available at: www.gov.uk.defra.

[10] BILITEWSKI, B.-URBAN, A.-FAULSTICH, M. : Schmelzverfahren Erfahrungen in Japan, Thermische Abfallbehandlung, 13. Fachtagung, Kassel University Press, Kassel, Germany, 2008.

[11] BEYCHOK, M. R. Process and environmental technology for producing SNG and liquid fuels, US EPA report EPA-660/2-75 $-011,1975$.

[12] GOODSHIP, V.: Management, recycling and reuse of waste composites, Woodhead Publishing, Cambridge, UK, 2010.

[13] FRANEK, J.-KOLLÁR, M.-MAKOVÍNY, I. : Microwave Electromagnetic Filed and Temperature Distribution in a Multilayered WoodCement Board, Journal of Electrical Engineering 62 No. 1 (2011), 25-30.

[14] SCHIEDER, D.-GRONAUER, A.-LEBUHN, M.-BAYER, K.-BECK, J.-HIEPP, G.-BINDER, S. : Prozess modell Biogas, Biogas Forum Bayern Nr. III 03/2010, ALB Bayern e.V., 2010, available at: https://www.biogas-forum-bayern.de/publikationen/Prozessmodell_Biogas.pdf/.

[15] Fachagentur Nachwachsende Rohstoffe e.V., Basisdaten Bioenergie Deutschland 2015, FNR, bioenergie.fnr.de,(2015) available at: http://www.fnr.de/fileadmin/allgemein/pdf/broschueren /Broschuere_Basisdaten_Bioenergie_2015_Web.pdf/ .

[16] ISCHOFSBERGER, W.-DICHTL, N.-ROSENWINKEL, K.-H SEYFRIED, C.-F. - BÖHNKE, B.: Anaerobtechnik, 2. Auflage, Springer-Verlag Berlin Heidelberg, Germany, 2005.

[17] ATV-DEVK, Thermische, chemische und biochemische Desintegrationsverfahren, Arbeitsbericht der ATV/DEVK Arbeitsgruppe AK-1.6 Klrschlammdesintegration, Hennef, Germany, 2003 .

Received 24 September 2015

František Janíček (Prof, Ing, PhD) graduated in power engineering from the Slovak University of Technology in 1979. In 1984 he gained the $\mathrm{PhD}$ degree. In 1999 he was appointed
Professor in power engineering. Since 1990 until now he has been a member of the Scientic Council FEI, and since 1995 a member of the Supervisory Board of the Western Slovak Energy Distribution Company. He is the founding member of the Slovak Committee of the World Energy Council. Professor Jancek is the Head Manager of the Project Qualication of Selected Electric Equipment of the Nuclear Power Plants in Slovakia and in the Czech Republic.

Milan Perný (Ing, PhD) was born in Slovakia in 1985. He graduated the Faculty of Electrical Engineering and Information Technology, Slovak University of Technology in Bratislava (SUT FEI) in 2009 as Diploma Engineer in Materials and technology. He is working in material science, photovoltaics and renewable energy sources research. At present he works at the Institute of Power and Applied Electrical Engineering, Slovak Technical University in Bratislava. Main interests of his research include DC and AC diagnostics methods in the eld of homo-junction and heterojunction solar cells.

Vladimír Š́ly (Prof, Ing, PhD) was born in Slovakia in 1956. Faculty of Electrical Engineering and Information Technology, Slovak University of Technology in Bratislava (SUT FEI) nished as Diploma Engineer (MSc) in Electrotechnology and in 1985 he received the scientic degree $\mathrm{PhD}$ from the same university. Since 200? he is Full Professor at SUT FEI. He works in material science, interesting especialy in dielectric and semiconductor structures and photovoltaic renewableenergy sources research.

Markus Giemza (Mgr, Ing) was born in Germany in 1961. He graduated from Faculty of Environmental Engineering of Politechnika Slaska in Gliwice (Poland) and Faculty of Environmental Engineering, degrees Mgr and Ing. In 1990 1991 was technical consultant for computer application and organization in Marburg (Germany). Since 2010 he has been as an external PhD student at SUT FEI.

Peter Hofmann (Ing) was born in Germany in 1969. He graduated from Technische Hochschule Mittelhessen in Giessen (Germany) degree: Ing (diploma in Energy and Heating Technology). In 19922012 was an excecutive manager in Eberbach Real Estate and excecutive manager in Hofmann Energy-Systems. Since 2012 he has been as an external PhD student at SUT FEI. 